\title{
For 150 years, UC science and agriculture transform California
}

Mark G. Yudof

President, University of California

G rowing up in West Philadelphia, the son of an electrician, I never had much occasion to encounter farm life. Our meat and potatoes came from the grocery store and our vegetables from the frozen food aisle. So one of the great privileges I have enjoyed as president of the University of California is learning about my adopted state's diverse agriculture industry and the amazing bounty it produces.

Having previously served as president of another landgrant college system, the University of Minnesota, I was no stranger to agriculture when I moved here in 2008. But I quickly found that nothing compares to California's agricultural legacy and the forward-thinking leadership of its farmers and ranchers. As UC president I meet regularly with the Advisory Commission on Agriculture and Natural Resources. I have had the opportunity to visit Central Valley farming communities, taste-test a new UC Davis olive oil blend, learn more about almond-growing than any of my city friends could imagine and even get a lesson in lettuce harvesting in the Salinas Valley.

As I have traveled through the state on these eye-opening excursions, I have been reminded many times of the critical contribution agriculture makes to the California economy and the prominent role our university plays in that industry. Whether you're a backyard gardener, a 4-H student, a small family farmer or a major national food producer, chances are what you raise has in some way benefitted from UC innovation and collaboration.

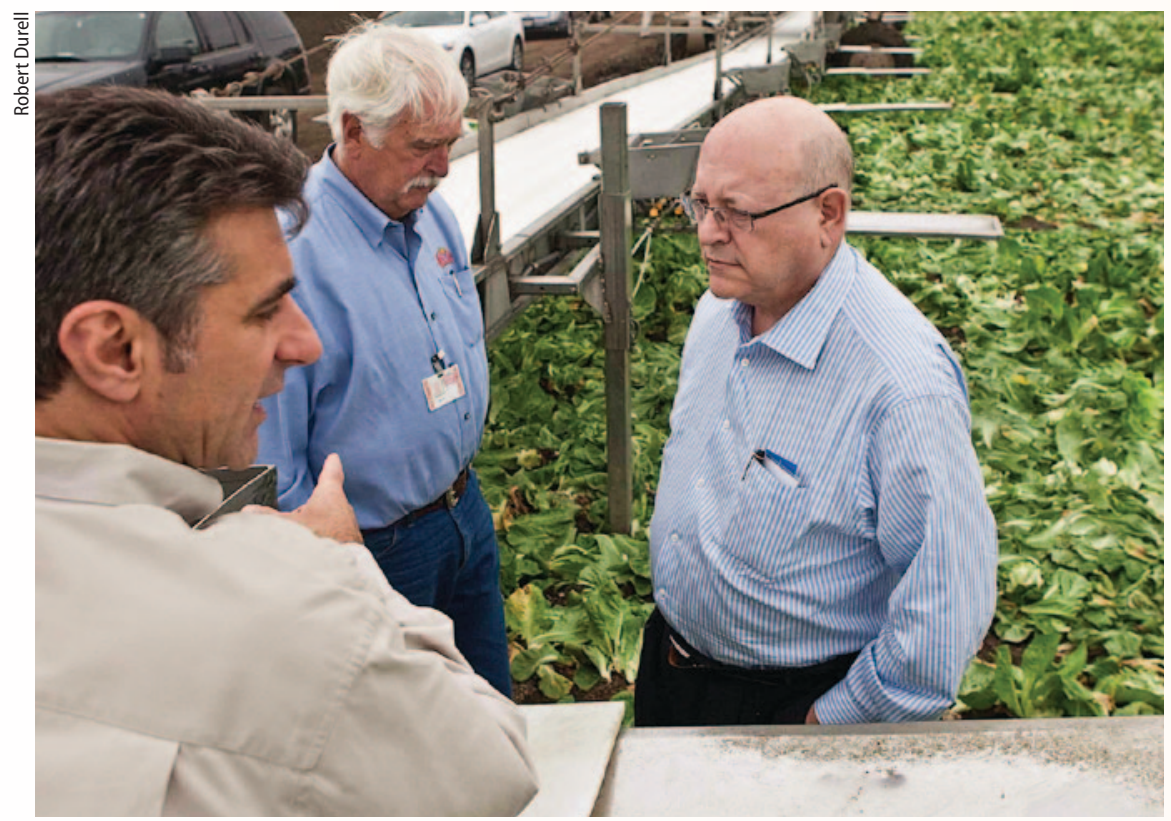

In 2010, UC President Mark Yudof (right) viewed harvesting practices designed to ensure freshness and food safety in a Salinas Valley lettuce field, with Jim Lugg (center) of Fresh Express and Tanios Viviani (left) of Chiquita Brands.
To name just a few examples, about $40 \%$ of the strawberries grown in the world come from UC-developed varieties.

UC Davis certifies $95 \%$ of the grapevines sold in California, providing our wine industry with a reliable supply of vines. I have even learned that canned fruit cocktail originated at UC when in the 1930s food science pioneer William Vere Cruess came up with a way to keep fruit from going to waste.

\section{Long-standing partnership}

From the hundreds of varieties of crops developed to methods of cultivation, irrigation, animal husbandry, pest control, processing and packaging - it is evident that the agriculture industry's long partnership with the university has been a profitable and mutually beneficial one.

Indeed, I would go as far as to say that UC might not have evolved into the world's greatest public university system nor would California agriculture have grown into the $\$ 37.5$ billion industry it is today if we hadn't teamed up nearly 150 years ago.

The catalyst for that partnership was, of course, the Morrill Land-Grant College Act, signed into law by Abraham Lincoln on July 2, 1862. This issue of California Agriculture celebrates the 150th anniversary of that landmark legislation in recognition of the impact it had on the future of California, our university and our nation (see pages 42-49).

It was the early days of the Civil War when Lincoln signed the law introduced by Vermont Congressman Justin Smith Morrill. The law granted federal land for states to fund colleges teaching agriculture and "the mechanic arts." At the time, our country was being split apart, yet Lincoln had the foresight to envision a future of peace and prosperity in a nation united and populated by an educated citizenry.

\section{Farmers' legislation}

The Morrill Act was part of a slate of so-called "farmers' legislation" Lincoln signed that year. Included were the laws that created the U.S. Department of Agriculture and the Homestead Act, which granted plots of land in the West for settlers to farm. He also signed the Pacific Railway Act, which cleared the way to build the transcontinental railroad. You can debate the politics that influenced the creation of these laws and some of the unintended consequences, but there is no question they collectively transformed our country.

With trains connecting East and West, settlers could travel with relative ease to the Western frontier. They could also 
